\title{
Трамп, Твиттер и фейковые новости (Trump, Twitter and Fake News)*
}

\author{
Munadhil Abdul Muqsith ${ }^{1}$, Rizky Ridho Pratomo², \\ Valerii L. Muzykant ${ }^{3}$ \\ ${ }^{1}$ Universitas Pembangunan Nasional "Veteran" Jakarta, Indonesia \\ ${ }^{2}$ Energi Bogor Indonesia, ${ }^{3}$ Peoples' Friendship University of Russia (RUDN) \\ University, Russia. \\ doi 10.15408/jch.v9i3.22445
}

\begin{abstract}
This study aims to provide rationality regarding Donald Trump as a fake news aggregator. Donald Trump's leadership from 2017-2020 is controversial and created a massive wave of fake news. As a populist leader, he often issued statements that confused the public during his reign, causing people's trust in the Trump administration to decline. He made the statement not only on national television but also on social media. Social media is the right political communication funnel for any populist leader when it comes to audience reach. Donald Trump is an active user especially on Twitter and uses it to spread misinformation and disinformation to spread what he calls as a truth. Many statements make Donald Trump worthy of being called a fake news aggregator. This study uses a qualitative approach with the content analysis method. Thirty-two samples of Donald Trump's hoax statements that were examined found that the hoaxes spread by him were not limited to just one topic. This research has both theoretical and practical significance. From a theoretical point of view, this research contributes to the development of literature regarding the relationship between hoaxes and populist leaders. In practical terms, this literature contributes to understanding the characteristics of populists and how social media is used as a funnel to spread hoaxes.

Keywords: Hoax; Donald Trump; Populism; social media; Twitter.
\end{abstract}

${ }^{*}$ Received: July 17, 2021, revised: December 23, 2021, accepted: December 25, 2021, Published: December 30, 2021.

${ }^{1}$ Munadhil Abdul Muqsith is a Doctor in International Journalism, Lecturer and Researcher at Pembangunan National Veteran Jakarta University. ORCID: http://orcid.org/0000-0003-1525-0136

${ }^{2}$ Rizky Ridho Pratomo is a Policy Analyst of the Energi Bogor Indonesia. ORCID: http://orcid.org/000-0003-3077-9345.

3 Valerii L. Muzykant is a Professor, Doctor of Sciences (Sociology) at Peoples' Friendship University of Russia (RUDN) University, Russia. ORCID: http://orcid.org/0000-0001-9422-351X

Corresponding Author: munadhil@upnvj.ac.id 


\title{
Trump, Twitter and Fake News
}

\begin{abstract}
Abstrak
Penelitian ini bertujuan untuk memberikan rasionalitas terkait Donald Trump sebagai fake news aggregator. Kepemimpinan Donald Trump pada periode 2017-2020 ini sangat kontroversial dan menciptakan sebuah gelombang fake news yang masif. Sebagai seorang pemimpin populis, dalam masa pemerintahannya, tak jarang dia mengeluarkan pernyataan yang menimbulkan kebingungan kepada masyarakat sehingga menyebabkan turunnya kepercayaan rakyat terhadap pemerintahan Donald Trump. Pernyataan itu dia lontarkan tidak hanya di media televisi nasional, tetapi juga media sosial. Bahkan, apabila berbicara jangkauan audience, media sosial menjadi corong komunikasi politik yang tepat bagi setiap pemimpin populis. Donald Trump merupakan pengguna aktif media sosial, khususnya Twitter. Donald Trump memanfaatkannya untuk menyebarkan misinformasi dan disinformasi untuk menyebarkan kebenaran versi miliknya. Ada banyak pernyataan yang membuat Donald Trump layak disebut sebagai fake news aggregator. Studi ini menggunakan pendekatan kualitatif dengan metode analisis konten. Sebanyak tiga puluh dua sampel pernyataan Donald Trump dikaji. Penulis menemukan bahwa berita bohong yang disebarkan olehnya tidak terbatas hanya satu topik semata. Penelitian ini memiliki signifikansi teoritis dan praktis. Dari segi teoritisnya, penelitian ini berkontribusi terhadap perkembangan literatur terkait hubungan antara hoaks dan pemimpin populis. Dalam segi praktisnya, literatur ini menjadi sumbangan pemikiran untuk memahami lebih lanjut karakteristik populis dan bagaimana media sosial digunakan sebagai corong untuk menyebarkan hoaks.
\end{abstract}

Kata Kunci: Hoaks; Donald Trump; Populisme; Media Sosial; Twitter

\section{Трамп, Твиттер и фейковые новости}

\begin{abstract}
Аннотация
Это исследование направлено на то, чтобы дать разумное представление о Дональде Трампе как агрегаторе фейковых новостей. Руководство Дональда Трампа в период 2017-2020 годов было очень спорным и вызвало массовую волну фейковых новостей. Как лидер популистов во время своего правления он часто делал заявления, которые вызывали замешательство у общественности, вызывая снижение доверия людей к правлению Дональда Трампа. Эти заявления он делал не только по национальному телевидению, но и в социальных сетях. Фактически, когда дело доходит до охвата аудитории, социальные сети являются правильной воронкой политической коммуникации для любого лидера популистов. Дональд Трамп - активный пользователь социальных сетей, особенно Твиттера. Дональд Трамп использует его для распространения недостоверной информации и дезинформации, чтобы распространить свою версию правды. Есть много заявлений, которые делают Дональда Трампа достойным называться агрегатором фейковых новостей. В этом исследовании используется качественный подход с методом контент-анализа. Были изучены 32 образца заявлений Дональда Трампа. Автор считает, что распространяемые им фейковые новости не ограничиваются одной темой. Это исследование имеет как теоретическое, так и практическое значение. С теоретической точки зрения, это исследование способствует развитию литературы о взаимоотношениях между обманом и популистскими лидерами. На практике эта литература является вкладом в дальнейшее понимание характеристик популистов и того, как социальные сети используются в качестве канала для распространения лжи. Ключевые Слова: Обман; Дональд Трамп; Популизм; Социальные Сети; Твиттер
\end{abstract}




\section{А. ВВЕДЕНИЕ}

Президентство Дональда Трампа закончилось в январе 2021 года. Однако с выборами Дональда Трампа и Хиллари Клинтон есть своя история. Четыре года назад, если быть точным, 2016 год стал временем, когда мировое сообщество познакомидось со словом «фейковые новости». Хотя сами по себе фейковые новости практикуются уже давно, они заслужили свое место в цифровом мире. Поиск в базе данных New York Times с 1 июля по 31 декабря 2016 года обнаружил 319 статей, в которых фигурировала фраза «фейковые новости». (Барклай, 2018). Влиятельный Словарь Колдинза даже назвал его «Сдовом года 2017», что является анекдотическим показателем общего пенитенциарного учреждения в то время. (Quandt, Frischlich, Boberg, \& \& Schatto-Eckrodt, 2019). Уникально то, что в том же году был избран Дональд Трамп, один из кандидатов в президенты Соединенных Штатов, и он победид Хиллари Клинтон.

Дональд Трамп - фигура попудистов, где он часто выражает разочарование в политической элите. Если говорить с политической точки зрения, то представление о процветающем политическом попудизме как о преследовании, направленном против истеблишмента, возглавляемом харизматическим лидером, превозносит родь «народа» и направлено на разделение политической арены и общества на «нас, народ» против «них, элит». (Zúñiga, 2020). Он позиционирует себя на стороне общества, которое было разочаровано пагубной элитной политикой. Особенно учитывая финансовый кризис 2008 года, потрясший экономику, поэтому в контексте Соединенных Штатов Дональд Трамп стал «фигурой спасителя», используя жаргон «Сделаем американца снова великим».

Одним из факторов, которые заставиди его победить на выборах, были его партизаны в цифровом мире. Цифровой мир, особенно в социальных сетях, стал источником информации, как точной, так и фальшивой. В социальных сетях масштабы и эффект распространения информации достигаются такими быстрыми и растущими темпами, что искаженная, неточная или ошибочная информация приобретает огромный потенциал, чтобы в считанные минуты оказать реальное воздействие на миллионы пользователей. (Фигейра и Оливейра, 2017). За три месяца до выборов 2016 года Трамп имел доступ к более чем 22 милдионам человек только через свои учетные записи Facebook, Twitter, Instagram и Reddit, в то время как Клинтон имел доступ к более чем 14 миллионам человек. Если разбить цифру в 22 милдиона, то разбивка будет следующей: 10 милдионов подписчиков в Facebook, 10 милдионов подписчиков в Twitter, более 2 
милдионов подписчиков в Instagram, и у него почти 200.000 подписчиков Reddit. (Хендрикс и Шилл, 2017).

Исподьзование этого персонажа в качестве основы одной из характеристик популистского деятеля - умение пользоваться социальными сетями. Потенциал социальных сетей огромен, особенно с точки зрения возможности подкдючения. Социальные сети позволяют в режиме реального времени связывать одного человека с другим из разных уголков мира. Им нужно только исподьзовать функцию подписки в раздичных социальных сетях, таких как Facebook, Twitter, YouTube и Instagram; они могут получать информацию от людей, на которых они подписаны (Schroeder, 2019). Следовательно, подитические дидеры могут быть в состоянии достичь своих целей не только за счет доступа к социадьным сетям на одной или нескольких платформах, но и за счет увеличения своей зависимости от сети сильных взаимосвязанных граждан, которые, комментируя, продвигая и обсуждая свое исходное сообщение, участвуют напрямую в глубоком распространении этих популистских идей (Zúñiga, 2020).

По этой причине Дональд Трамп использует социалыные сети в качестве основного канала коммуникации. Это форма удовлетворения за исподьзование социальных сетей. Однако, помимо того, что идентифицирует Донадьда Трампа с социальными сетями, почти нередко Дональд Трамп связан с фадьшивыми новостями. Если посмотреть на количество последователей или подписчиков в социальных сетях Дональда Трампа, это число может быть исподьзовано в качестве оружия для распространения ложных новостей им самим или его командой. Например, Трамп утверждает, что подьзуется поддержкой видного католического деятеля Папы Франциска. Однако, после уточнения, новость оказалась ложью. Хотя вдияние фейковых новостей по-прежнему трудно объяснить и измерить, одно можно сказать наверняка: Трамп внес фейковые новости в свою политическую повестку дня. Это исследование целенаправленно объясняет рациональность того, почему Трампа называют агрегатором фейковых новостей.

\section{Б. МЕTOД}

В этом исследовании авторы исподьзовали качественный исследовательский подход, который был выбран в качестве метода исследования. Контент-анализ - это хорошо зарекомендовавший себя метод 
анадиза данных, который развился в процессе обработки текстовых данных. (Kleinheksel, Rockich-Winston, Tawfik, \& Wyatt, 2020) Контент может поступать из раздичных источников: книги, рукописи, изображения, фотографии, записанные разговоры, видеозаписи, сообщения в электронных списках рассылки и онлайн-форумах, сообщения в блогах и т.д. (УИлсон, 2016)

По словам Динчера (2016), контент-анадиз можно использовать в прикладных и теоретических исследованиях. Он приводит два примера использования контент-анадиза в качестве метода. Во-первых, исследователь считает и классифицирует слова с помощью измерительного прибора или вычисляет их частоту или содержание обмана Трампа в случае этого исследования. Во-вторых, исследователь кодирует и классифицирует данные на основе интервью. (Dinçer, 2018)

\section{В. РЕЗУ ЯЬТАТЫ И ОБСУЖДЕНИЕ}

\section{1. Дональд Трамп и Twitter}

При анализе мотивации фейковых новостей есть две программы распространения фейковых новостей: деньги и идеология (Allcott \& Gentzkow, 2017). Деньги - самый влиятельный фактор в распространении фейковых новостей, потому что, когда подьзователи нажимают на новости, производители получают доход. Второй - подитический мотив, когда у производителей есть определенная политическая повестка дня иди на стороне одного из лагерей. Первая мотивация Трампа не особо интересует. Однако это совсем другое дело, если новость благоприятна или поднимает имя Дональда Трампа в подитической повестке дня. Эта точка зрения предполагает, что третья сторона, распространяющая фейковые новости сама по себе, похожа на случай мальчика из Румынии. Однако, если это будет не в его пользу, Дональд Трамп опровергнет эту новость.

Одним из примеров того, как Дональд Трамп, похоже, избегает запросов СМИ, является то, как CNN и Buzzfeed связали его с Россией. Во время пресс-конференции в Trump Tower Дональд Трамп отказался отвечать на вопросы журналистов CNN. Помимо отказа, Трамп также атаковал СМИ. Трамп неоднократно критиковал CNN и BuzzFeed на своей пресс-конференции в Trump Tower в Нью-Йорке в среду, называя BuzzFeed «левым блогом» и «неудавшейся грудой мусора» за публикацию непроверенных отчетов. (Джеймисон, 2017). Другой случай произошел, 
когда в декабре прошлого года несколько СМИ, таких как Variety, сообщили, что Дональд Трамп планировал стать исполнительным продюсером фидьма «The Celebrity Apprentice», когда станет президентом. Однако Трамп отрицал это и заявил в социальных сетях, что новости были фальшивыми (Coll, 2017).

Здесь Дональд Трамп говорит, что распространяемые новости являются фальшивыми или ложными, когда они его дискредитируют. Из этого можно сделать вывод, что он не хочет, чтобы его политический имидж был разрушен. Ещё одна интересная закономерность заключается в том, что когда появляются искаженные новости против него, Трамп почти часто исправляет их через социальные сети Twitter. По словам советников Дональда Трампа, Твиттер - его любимое средство общения, где Трамп пишет твиты нескодько раз в день (Walsh, 2017).

Если вы посмотрите на количество подписчиков Трампа в Твиттере, то на 16 января 2017 года ему удалось достичь 19,92 миллиона (Salkowitz, 2017). Это, безусловно, большое количество, даже несмотря на то, что есть некоторые неясные формы ботов, спама и учетных записей, которые не взаимодействуют напрямую. В этом преимущество социальных сетей, где пользователь может взаимодействовать и распространять информацию среди милдионов дюдей во всем мире. В одном исследовании преимущества социальных сетей, особенно с учетом того, скодько способов они могут выражать свое мнение в раздичных формах, таких как лайкание постов и фотографий, комментирование обновлений, обмен комментариями к другим постам, анонимное выражение мнений, критика других (Whitling \& Williams, 2013).

Дональд Трамп изучил эти три преимущества. Как 45-й президент США, Трамп использует Твиттер для распространения новостей, столкновений с критиками и даже для дипломатических действий (Pain \& Chen, 2019). Это использование все ещё распространено, потому что, согласно некоторым исследованиям, люди использовали Твиттер для этих целей. В исследовании Whitling \& Williams (2013), было обнаружено, что люди исподьзуют Твиттер для социального взаимодействия (88 процентов), поиска информации (80 процентов), досуга (76 процентов), развлечений (64 процента), релаксации (60 процентов). Коммуникационная полезность (56 процентов), выражение мнения (56 процентов), удобство использования (52 процента), обмен информацией (40 процентов), а также наблюдение и наблюдение за другими (20 процентов) (Whitling \& Williams, 2013). 
Визуально использование Твиттера Дональдом Трампом аналогично исподьзованию широкой публикой (Roca-Cuberes \& Young, 2020). Однако при дальнейшем рассмотрении, учитывая его обстановку на посту президента, Твиттер в основном используется как политический инструмент. По словам Нуссельдера, Твиттер рассматривается как посредник между новыми медиа, исподьзуемыми для действий и подитики, и основными СМИ в качестве подитического инструмента. Однако, добавдяет Нуссельдер, Твиттер стирает раздичие между объективностью и субъективностью, потому что с точки зрения формы сообщения твиты в чем-то похожи на личные сообщения, отправляемые между группами - частные, опубликованные, политические сообщения (Нуссельдер, 2013). Во время выборов Твиттер стал самым важным средством политической коммуникации. Чем больше кандидатов исподьзуют Твиттер для передачи своих мыслей, тем бодьше людей ретвитят их, распространяют свои сообщения, а журналисты упоминают твиты при освещении выборов, создавая благоприятный круг, который привлекает больше внимания к платформе микроблогов (Buccoliero и др. 2018). Более того, Твиттер стал политическим инструментом Дональда Трампа. Твиттер помог Трампу избежать негативного освещения в основных СМИ, таких как The New York Times и AВC News (Ecker, Jetter, \& Lewandowsky, 2020). Например, когда СМИ сообщили, что Трамп заплатит 25 миллионов долларов за завершение Университета Трампа, он написал в Твиттере о споре о Гамильтонской игре (Ecker, Jetter, \& Lewandowsky, 2020).

Это смешение фактов и вымыслов, - вот почему Дональд Трамп любит Twitter (ВВС, 2020). До закрытия аккаунта Донадьда Трампа в Твиттере активность Трампа в твитах с 2018 по 2020 год росла. На основе архива Твиттер, архив показывает, что Трамп твитнул или ретвитнул около 3500 раз в 2018 году, 7700 раз в 2019 году и более 12000 раз в 2020 году. Кроме того, в начале своего правления Трамп писал в Твиттере 5,7 раза в день, а затем во второй половине 2020 года, увеличившись более чем в шесть раз до 34,8 раза (McCarthy, 2021). Эта частота подтверждает, что Трамп действительно использует Твиттер как политический инструмент.

Одно исследование выявило три темы, которые Трамп часто поднимает в Твиттере: аутсайдеры, которые снова сделают американцев великими; расизм, женоненавистничество и язык вражды; поддельные новости (Pain \& Chen, 2019). Другое мнение гласит, что при использовании Твиттера есть пять тем, которые часто появляются в их твитах: версия Соединенных Штатов, в которую на самом деле вторглись захватчики; 
настоящие американцы это видят; Трамп обладает уникальной квалификацией, чтобы остановить это вторжение; Истебдишмент и его агенты стоят на моем пути; из-за этого США находятся в серьезной опасности (Хамфри, 2021).

При дальнейшем рассмотрении указанные темы характерны для правых популистов. Расизм, сопротивление элитам - некоторые из их политических программ. Например, когда Дональд Трамп написал в Твиттере негативные настроения против иммигрантов из Мексики. В контексте фейковых новостей твит Трампа описывает, как он исподьзует этот термин в качестве оружия для атаки на дискурс, который не соответствует его мировоззрению или раскрытым фактам; он предпочитает быть скрытым (Pain \& Chen, 2019).

\section{2. Дональд Трамп и фейковые новости}

Дональд Трамп использовал Twitter как средство коммуникации с более широким сообществом. Однако Трампа также связывают с фейковыми новостями (Carr, 2018). Учитывая природу цифровых медиа, нет сомнений в том, что Трамп может взаимодействовать и быстро реагировать, когда о нем появдяются негативные новости. Итак, когда мы говорим о фейковых новостях и Трампе, есть определение, что фейковые новости для Трампа - это фальшивые новости, которые считаются вредными. Келлнер назвал Трампа самым большим джецом в истории президентства США за то, что он неоднократно говорид большую ложь независимо от фактов и эмпирических данных (Kellner, 2018).

Между тем определение фейковых новостей поднималось многими учеными. Однако под фальшивыми новостями подразумевается нечто большее, чем сам термин: фундаментальный сдвиг в политическом и общественном отношении к тому, что представдяют собой журналистика и новости, а также к тому, как факты и информацию могут быть получены в цифровом мире (Ecker, Jetter, \& Lewandowsky, 2020). Это заявление уместно, когда сталкиваешься с условиями, в которых подитики создают фейковые новости, особенно популистский способ политической коммуникации.

Однако он делал неверное заявление не только в Твиттере. В нескольких случаях, через пресс-секретаря или в телешоу, Трамп довольно часто делает ложные заявления, не основанные на фактах (Clayton, 2021). Например, на президентских выборах 2020 года Трамп в своем выступлении 
в Белом доме заявил, что избирательный процесс был сфальсифицирован (Snith, 2020).

Что касается популизма, он способствуют распространению фейковых новостей. Мадьдонадо (2019) говорит, что популизм отвергает правду основных СМИ, и подчеркивает, что истина находится не там, а в движениях или СМИ, которые осмеливаются бросить вызов власти. Это имеет смысл, потому что это может повысить доверие к альтернативным СМИ независимо от того, ясен ли источник информации, так что некоторые фейковые новости получают хороший отклик (Мальдонадо, 2019).

Кроме того, наличие социальных сетей является для популистских дидеров ускорителем распространения мнений иди идей, в которые они верят. Это также подтверждается отношением подьзователей социадьных сетей к тем новостям, которые соответствуют их убеждениям и мнениям, независимо от того, новости верны, подлинные или, поддельные (Akgül, 2019). Например, используя пример кампании в США, есть 115 фейковых новостей от сторонников Трампа по сравнению с 41 фейковой новостью, опубликованной сторонниками Хиллари Клинтон. Сторонники Трампа знают, что социальные сети стали рупором современного общества (Crawford, 2017). В результате, пользуясь преимуществами социальных сетей, Трамп может использовать их в своих интересах. Особенно если вы посмотрите на интенсивность твитов Трампа, нельзя отрицать, что Трамп стал агрегатором фейковых новостей. Согласно стенограммам и сообщениям в социальных сетях, собранным Factba.se и рассмотренным The Independent, с тех пор, как фраза «фальшивка» впервые появилась в Твиттере в декабре 2016 года, Дональд Трамп произнес слово фейковые новости 1906 раз (Woodward, 2020).

По словам автора, фейковые новости, упомянутые Трампом, превратились в маркировочную фразу. Вот что происходит, когда эта фраза исподьзуется как своего рода инструмент политической коммуникации для политиков. Значение теряется и становится слишком субъективным (Morris, 2020). Его статус президента также поддерживает Трампа, поэтому такая маркировка оказывает определенное вдияние на общество. Тенденция маркировки может привести к разрушению общественной оценки на объективный факт.

Например, когда произошел COVID-19, Трамп сделал много ложных заявлений, которые омрачили общественное мнение о серьезности ситуации. Он раскритиковал СМИ за сообщения о нестабильной ситуации 
с COVID-19 в США. В своем твите он обвинил СМИ MSDNC (Comcast) и CNN в фейковых новостях: Цитата из твиттер-аккаунта Дональда Трампа:

«Фейковые новости с низким рейтингом MSDNC (Comcast) и @CNN делают все возможное, чтобы коронавирус выгдядел как можно хуже, включая панику на рынках, если это возможно. Точно так же их некомпетентные товарищи-демократы все говорят, никаких действий, ничего не делают. США в отличной форме! @CDCgov "@CDCgov (Уэйкфилд, 2021).

Даже когда дело доходит до COVID-19, Трамп часто идентифицирует его как вирус из Китая. Это заявление носит политический характер, потому что Трамп, похоже, хочет найти козла отпущения за хаос в своей стране. Один из его твитов был следующим:

«Я всегда очень серьезно относился к китайскому вирусу, и поступил очень хорошую работу с самого начала, включая моё очень раннее решение закрыть «границы» с Китаем - вопреки желанию почти всех. Было спасено много жизней. Новое повествование The Fake News позорно и ложно!» (Сому, 2020).

Когда дело доходит до методов подитиков-популистов, основной метод популистов заключается в создании публичного страха и в идентификации коздов отпущения, которых обвиняют в нанесении ущерба или угрозе уничтожения нашему (изначально хорошему) обществу (Bergmann, 2020). Потому что политикам-популистам легче найти козла отпущения, чем найти решение. Это было доказано, когда США стали страной с крупнейшими случаями COVID-19 (Rosenberg, Williams, \& Nimashaun, 2020). Это «достижение» показывает, что Трамп ничего не делает и слишком занят, чтобы обозначить инакомыслие и дискредитировать его.

Тенденции Трампа ошибочны и неточны, потому что он хочет создать альтернативную версию реальности. Однако Бергманн (2019) утверждает, что не вся высказываемая ложь направлена на то, чтобы убедить общественность в альтернативной реальности или поддержать конкретную реальность. Наоборот, заявление Трампа можно интерпретировать как спонтанное и неточное измышление, обсуждаемое для замены и изменения того, что считается истинным и приемлемым (Bergmann, 2020).

Однако, будь то спонтанная или преднамеренная манипуляция, объективность редко встречается, когда дело касается Донадьда Трампа. 
Интерпретация более субъективна, чтобы соответствовать тому, что считается верным. Это становится опасностью, когда объективные факты отбрасываются, потому что это причиняет вред обществу.

\section{3. Дональд Трамп как агрегатор фейковых новостей}

Исходя из приведенных выше аргументов, автор считает, что Трамп стал агрегатором фейковых новостей не только в Твиттере, но и при любой возможности, такой как пресс-конференции, интервью и так далее. Поэтому важно классифицировать типологию фейковых новостей, которые часто высказывает 45-й президент.

Существует несколько типологий фейковых новостей, созданных многими учеными. Например, существует шесть типологий фейковых новостей, вкдючая сфабрикованные новости, сатиру, пародию на новости, манипуляции с фотографиями, пропаганду, а также рекламу и связи с общественностью (Tandoc, et.al. 2018). Другие добавиди несколько типодогий, таких как клик-приманка (click-bait), слухи, субъективные предположения, тревожные разговоры, новости пользовательского контента и новости с ложными данными (Wang, Rao, \& and Sun, 2020). Однако для целей этого анадиза авторы используют типологии из Докдада Совета Европы: сатира иди пародия, вводящий в заблуждение контент, ложный контент, манипуяируемый контент, яожный контекст, ложные связи и иожный контент (Wardle \& Derakhshan, 2017). Эта типология делится на три большие категории, а именно недостоверная информация, дезинформация, и недобросовестная информация.

\section{Рисунок 1 \\ Типологии фейковых новостей}

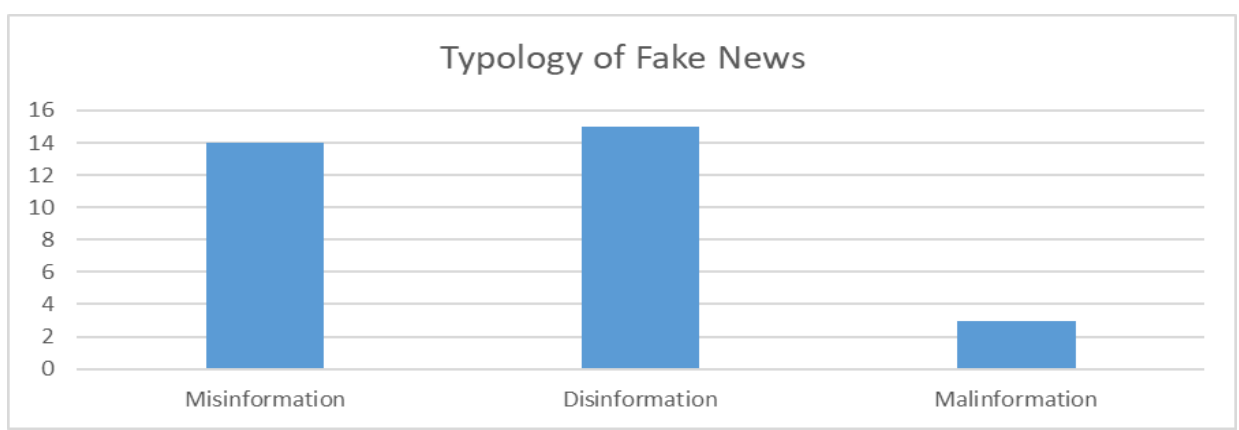

Source: factcheck.org 
Когда дело доходит до трех основных категорий, упомянутых выше, Трамп часто делает заявления, которые имеют тенденцию к недостоверной информации и дезинформации. Цифра довольно сбалансированная: 15 за дезинформацию и 14 за недостоверную информацию. Что касается неверной информации, то Трамп исподьзует ее редко, всего трижды. Однако это всего дишь образец, и не искдючено, что это число будет продолжать расти.

Восприятие общественностью США недостоверной информации и основных СМИ вызывает беспокойство (van der Linden, 2020). Опрос, проведенный в 2018 году Knight Foundation и Gallup, показал, что 39\% американцев считают, что новости, которые они видят по телевидению, читают в газетах и сдышат по радио, явдяются неверной информацией. Хотя 65\% новостей находится в социальных сетях, американцы считают, что это неверная информация. Если восприятие недостоверной информации объединяется в идеологии, 51 процент республиканцев и 54 процента консерваторов считают, что новости, циркулирующие в основных средствах массовой информации, таких как телевидение, радио и газеты, являются недостоверной информацией (Knight Foundation, 2018).

\section{Рисунок 2}

\section{Темы фейковых новостей}

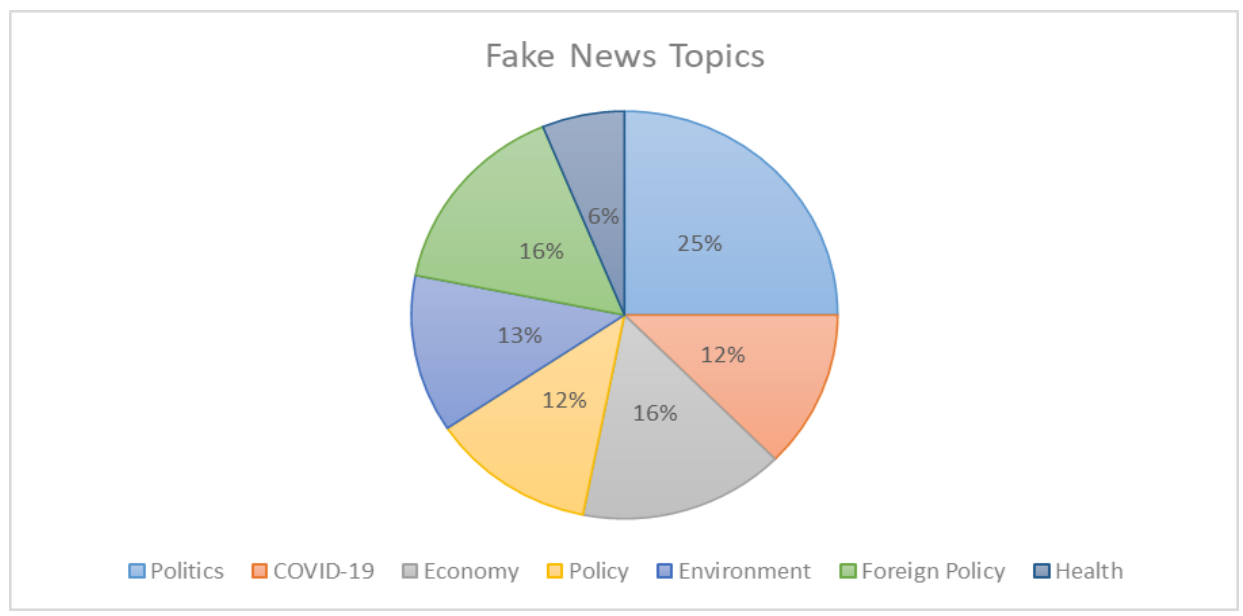

Source: factcheck.org

Если вы посмотрите на часть тем, которые часто обсуждаются Дональдом Трампом, у политики самый большой относительный процент. По политическим вопросам Трамп с большей вероятностью 
дискредитирует своих политических оппонентов. Это отражается в том, что Трамп позиционирует себя как спасителя, в то время как его противники, демократы, являются элитой. Эти усилия помогли укрепить собственное положение и имидж Трампа как политика, поддерживающего свой народ (Pew Research Center, 2021). Между тем, тема COVID-19 возникнет в 2020 году, когда пандемия поразит мир (Muqsith, Pratomo, Kuswanti, \& Muzykant, 2021).

Возьмем к примеру проблему иммигрантов. Трамп напал на демократов по поводу политики DACA, потому что он утверждал, что она исходит от демократов, и из-за этой подитики семьи должны быть разделены (Sacchetti, 2021).

«Я знаю, что сейчас вы переживаете очень сильно насчет разделения семей. Но это плохие законы, которые нам дали демократы. Мы должны разбивать семьи. Демократы дали нам этот закон. Это ужасно. Мы доджны разбивать семьи. Демократы дади нам этот закон, и они ничего не хотят с этим делать. Они так и оставят, потому что не хотят ничего менять. А теперь вы разбиваете семьи из-за демократов. Это ужасно. (Gore, 2018).

Это заявление вызвало у общественности негативное отношение к Демократической партии и предыдущему президенту; Особенно если вы посмотрите на его заявление, в котором подчеркивается разделение семьи, что может вызвать сочувствие у тех, кто прочитает его заявление (Gore, 2018). Хотя было подтверждено, что фактическая администрация Буша из той же партии, что и Дональд Трамп, реализовывала эту политику, нельзя отрицать, что проблема разделения семей заставила людей рассматривать демократов как не имеющих сочувствия при разработке законов.

\section{Рисунок 3 \\ Типодогии фейковых новостей}

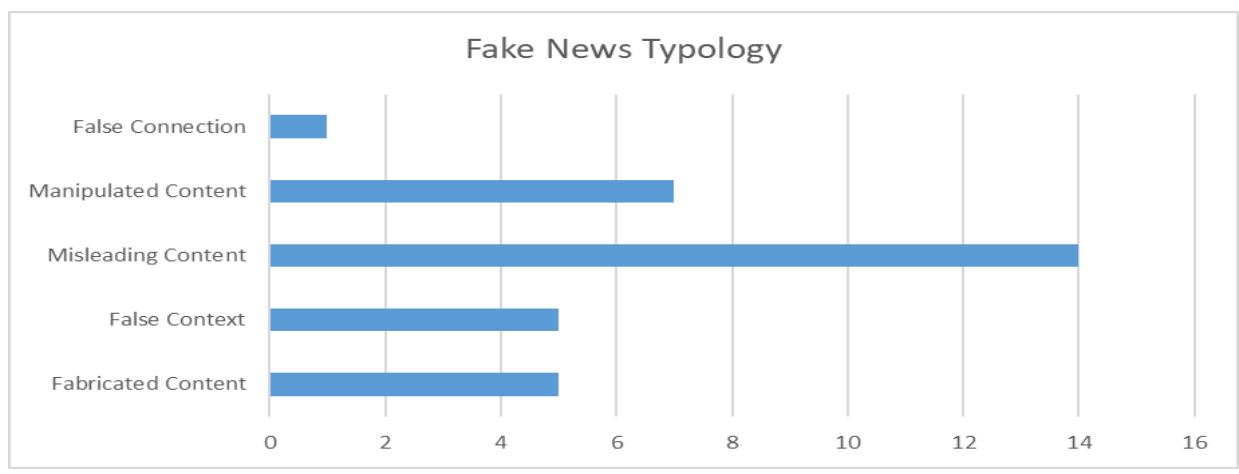


Замечания Трампа о демократической политике разделения семьи относятся к категории вводящего в заблуждение содержания. Основываясь на 32 образцах, взятых авторами за период с 2017 по 2020 годы, наибодьшее количество контента было вводящим в заблуждение. С точки зрения понимания, этот тип контента направлен на то, чтобы выставить в плохом свете проблемы или отдельных лиц. В понимании Дональда Трампа, он хочет обвинить кого-то в своих бедах с двумя целями: дискредитировать партию и укрепить свою репутацию лидера, которого хочет видеть его народ. И эта цель применяется не только к вводящим в заблуждение типам контента, но и к другим типам контента.

Выше автор привел пример, но автор хотел бы предоставить другую илдюстрацию, относящуюся к другой категории - надуманному контенту. Короче говоря, это заявления, сделанные с целью причинить вред другим (Робертсон, 2019). Например, Трамп заявил, что Обама прослушивал его. В заявлении в Твиттере его настроения, похоже, нападают на Обаму: «Ужасно! Только что узнал, что у Обамы были «перехвачены провода» в Башне Трампа незадолго до победы. Ничего не найдено. Это маккартизм (McCarthyism)!» Заявления Трампа безосновательны, и намерение Трампа оклеветать Обаму состоит в том, чтобы разрушить его политический имидж и повысить его престиж. Причем претензия была сделана после президентских выборов, на которых он победил на выборах главы региона. ФБР не нашло доказательств, которые привели к обвинениям Трампа (Levitz, 2017).

Затем был другой пример, когда Трамп связал Байдена с Украиной в 2019 году. Байдена обвинили в удержании некоторых денег в Украине, так как украинское правительство не сняло с должности прокурора, который преследовал сына Джо Байдена, Хантера. Это заявление последовало после расследования, проведенного газовой компанией в Украине по поводу коррупции. В компании Хантер работал комиссаром. Позднее это утверждение было исправлено недавно назначенным прокурором Украины Юрием Ауценко. Он заявил, что Хантер не нарушал никаких законов в Украине, и добавил, что это расследование проводилось до того, как Хантер вступил в ряды должностных лиц газовой компании (Jacobson, 2019).

Заявления Дональда Трампа, конечно, безосновательны, но они направлены на дискредитацию Джо Байдена. Нацелившись на его сына, Трамп надеется, что общественность не поверит ему, особенно Джо Байдену, как сильному кандидату против Трампа на президентских выборах 2020 года. Таким образом, можно сказать, что Трамп инициировал 
попытки подорвать доверие к своим подитическим оппонентам (Lemire, Miller, \& and Weissert, 2020).

Затем еще одна ложь, которую совершил Трамп относительно своей пограничной политики. Трамп в своей кампании настаивал на том, что Мексика оплатит строительство пограничной стены. 45-й президент хотел показать, что сдержал слово. Поэтому он несколько раз заявлял о своих успехах в финансировании Мексики. В 2019 году Трамп заявил в Twitter, что:

«Мексика оплачивает строительство стень в ралках новой торговой сделки USMCА. Большая часть стень уже была полностью отремонтирована или построена. Мьг проделали большую работу. 5,6 миллиарда долларов, одобренных Хаусом - это очень мало по сравнению с вызодами национальной безопасности. Быстрая окупаемость! " (Кейт, 2019).

Однако, конечно, необходимо проверить истинность его заявления. Хотя в своем заявлении Трамп упомянул Мексику, необходимо изучить механизм финансирования. Он сказал, что Мексика заплатит за это через механизм соглашения USMCA. В этом случае по состоянию на декабрь 2018 года не было заявления о том, что Мексика заплатит за это. Несмотря на аргумент президента о том, что Мексика будет опосредованно выплачивать пособия, расчет пособий не имеет смысла. Поэтому заявление Трампа можно расценить как недостоверную информацию.

Одну из последних типологий, а именно неверную информацию, можно увидеть из заявления Трампа по проблеме изменения климата:

«Я думаю, что что-то происходит. Что-то меняется, и это снова изменится. Я не думаю, что это розыгрыш; Думаю, разница есть. Но я не знаю, что это сделано руками человека. Я скажу это. Я не хочу давать триллионы и триллионы долларов. Я не хочу терять миллионы и миллионы рабочих мест. Я не хочу, чтобы меня ставили в невыгодное положение (Муксит и др., 2020).

Если мы рассмотрим заявление Трампа выше, это заявление болезненно для активистов и тех, кому небезраздично изменение кдимата. США являются одним из крупнейших загрязнителей в мире, поэтому США должны участвовать в процессе смягчения последствий, чтобы защитить Землю от угрозы изменения климата. Однако Трамп скептически относится к тому, что изменение климата вызвано дюдьми. Хотя действительно, с одной стороны, явление таяния дьда в Гренландии сложно связать с 
деятельностью человека; Нельзя отрицать, что деятельность человека много веков назад способствовала изменению погодных условий на Земле (Denchak, 2021).

К счастью, американцы осознают реальность изменения кдимата. Согласно опросу, проведенному исследовательским центром Pew Research Center в 2019 году, 62\% американцев заявили, что изменение кдимата влияет, по крайней мере, на их ближайшие сообщества, и эта цифра выросла с 59\% в прошлом году. Глядя на эти цифры, конечно, то, что сказал Трамп, не вдияет на общественное мнение об изменении кдимата. Однако президент сверхдержавы, одного из крупнейших мировых загрязнителей, говорит, что это оказывает неоспоримое воздействие (WORLAND, 2016).

Кроме того, Дональд Трамп также заявил, что Парижское соглашение имеет юридические обязательства. В его заявлении говорится:

«Риски растут, поскольку исторически эти соглашения имеют тенденцию становиться все более и более амбициозными со временем. Другими словами, Парижские рамки - это всего хищь отправная точка, какой бы плохой она ни была, а не конечная точка. И выход из соглашения защищает Соединенные Штаты от будущих посягательств на суверенитет Соединенных Штатов и огромной будущей юридической ответственности. Поверьте мне, мы понесем огромную юридическую ответственность, если останемся в Парижском соглашении". (Схипани, Кихи, Робертсон, и Фарли, 2017)

Не только в отношении Парижского соглашения о внешней политике, отношения США с НАТО были также обострены его заявлением, в котором говорилось, что вклад стран-членов НАТО существенно уменьшился. В его заявлении говорится:

"До прошлого года, когда я посетил свою первую встречу, она снижалась объем денег, расходуемых странами, уменьшался и уменьшался очень существенно». Это утверждение неверно, хотя в 2015 и 2016 годах расходы европейских стран и Канады увеличились, а именно на 1,83 процента в 2015 году и 3,14 процента в 2016 году. В долларовом выражении с 2014 по 2016 годы освоенные средства увеличились на 5 проиентов». (Аипперт, 2016).

Нельзя отрицать, что часто ошибочные заявления Дональда Трампа сбивали с толку как его друзей, так и врагов. Однако серьезность удара остается неопределенной. В целом мы можем получить представление о 
влиянии фейковых новостей на общество. Например, в случаях, когда фейковые новости доходят до их ближайшего окружения. Аюди склонны полагать, что новости, которыми они делятся со своими друзьями, точны, поэтому они готовы делиться ими с другими. Однако, если после проверки окажется, что это фейковые новости, это может подорвать доверие, и человек, делясь этим, будет смущен и, в крайнем случае, удален из группы WhatsApp. (Даффи, Тандок, и Линг, 2019)

Не последнюю родь играет феномен, закдючающийся в том, что треть американцев не доверяет основным средствам массовой информации. Можно ли задать вопрос основным СМИ: почему они освещают фейковые новости? Есть несколько основных причин. Во-первых, это ценность хороших новостей и восприятие основных СМИ как хранителей истины. Другими словами, они могут исправить распространяющиеся фейковые новости. Однако вторая причина - эффект присоединения к бодьшинству. Поскольку есть средства массовой информации, которые тоже освещают их, другие средства массовой информации также освещают их, особенно если это следует их идеологическому стилю (Tsfati, et al., 2020).

Учитывая роль основных СМИ и слишком большое доверие к другим социальным кругам, доверие уязвимо, его легко сломать. Фейковые новости разрушают доверие человека и могут привести к конфликту, по крайней мере, на индивидуальном уровне. Крах доверия порождает скептическое общество. С одной стороны, в такую эпоху этот скептицизм необходим, чтобы отфильтровывать фадьшивые новости. Скептики склонны к критическому мышлению, поэтому у них есть мотивация проверить правдивость рассказа. Однако, с другой стороны, скептикам будет сложно создать кдимат доверия среди людей. Аюди будут бодее подозрительно относиться к другим, что затруднит установление доверия в социальных кругах (Logo Pew Research Center, 2020).

Также существует корреляция с уровнем принятия президента среди самих американцев. За четыре года пребывания у власти Донадьд Трамп не достиг и половины американцев - около 49 процентов. Сорок девять процентов - это наивысший показатель одобрения Донадьда Трампа на посту президента. Фактически, за время его пребывания в должности его рейтинг одобрения составлял всего 35 процентов (Gallup, 2021). Обама также получил небольшой рейтинг одобрения - всего 38 процентов в 2011 году. Однако доводьно часто Обама подьзуется одобрением более половины американцев, и самый высокий рейтинг был в первый 
президентский срок Обамы - 69 процентов. Кроме того, на протяжении 2016 года уровень одобрения Обамы продолжал расти (Gallup, 2017).

Прежде всего, растущее массовое распространение фейковых новостей и более частые ложные заявления Дональда Трампа вызывают недоверие общественности. Опрос, проведенный Pew Research Center в 2019 году, показал, что фейковые новости (50\%) представляют собой более опасную угрозу, чем изменение климата (46\%) и терроризм (26\%). Кроме того, 68\% американцев считают, что фейковые новости вдияют на их уровень доверия к правительству. 54\% американцев считают, что фейковые новости влияют на уровень доверия окружающих. 51\% американцев говорят, что фейковые новости вдияют на их уровень доверия к политическим лидерам в плане выполнения их работы (Mitchell \& Gottfried, 2019).

Тридцать два образца, которые взяли авторы - это лишь некоторые из множества ложных заявлений Дональда Трампа. Эти образцы можно использовать в качестве оправдания того, что Дональду Трампу удалось снизить доверие между общественностью США и правительством. Более того, он часто делает заявдения, которые заставдяют людей не понимать проблему. Фактически, как президент, Трамп должен был быть мудрее в решении проблем и не делать неправильных заявлений общественности. Это может быть фатальным, если президент также будет «продвигать» вымышленные новости, а не факты.

\section{Г. ЗАКАЮЧЕНИЕ}

В связи со всеми этими фактами есть три причины, по которым Трампа можно назвать агрегатором фейковых новостей. Во-первых, Дональд Трамп стал актером, причастным к фейковым новостям через свои заявления Его как президента сверхдержавы можно назвать неэтичным, потому что его следует исподьзовать как инструмент для успокоения общественности и распространения правды, независимо от последствий.

Во-вторых, это влияние ощущает не только американский народ, но и весь мир. Например, США вышли из Парижского соглашения. Соглашение требует приверженности всех стран делу спасения планеты, но Трамп легко ушел по причинам юридической ответственности. Хотя Трамп также слегка признал, что изменение кдимата было реальным, от него не было никаких реальных действий. Кроме того, их отношения с НАТО 
усугубляются заявлениями о существенном сокращении бюджета НАТО. Это привело к тому, что союзники США подвергли сомнению обязательства США перед НАТО. В 2020 году Трамп не стал охлаждать глобальную ситуацию с COVID-19, а вместо этого обвинил ВО3 и назвал COVID-19 китайским вирусом. Трамп портит отношения со своими гражданами, а также отношения с другими странами. Соединенные Штаты во времена Дональда Трампа потеряли свою силу и превосходство из-за позиции Дональда Трампа.

Во-третьих, Дональд Трамп помог создать атмосферу общественного скептицизма в отношении правительства и его партнеров. Скептически относиться к правительству естественно, но падение доверия к другим - совсем другое дело. Гармоничное общество - это общество взаимного доверия. Однако наличие фейковых новостей портит его. Нарушение общественного доверия может создать нестабильность в обществе. На государственном уровне есть случаи фейковых новостей, которые повредиди отношениям между странами, например, убийство Самуэля Пати, которое за оскорбление ислама оказалось детищем ребенка, который боялся тирады своих родителей (Арбар, 2021).

\section{БИБЛИОГРАФИЯ}

Akgül, H. (2019). Fake News as a Tool of Populism in Turkey: The Pastor Andrew Brunson Case. Polish Political Science Review., 7(2), 32-51.

Allcott, H., \& Gentzkow, M. (2017). Social Media and Fake News in the 2016 Election. Journal of Economic Perspectives, 31(2), 211-36.

Arbar, T. F. (2021, 03 11). Retrieved 04 10, 2021, from https://www.cnbcindonesia.com/news/20210311092122-4-229421/gegerpemenggalan-guru-prancis-hasil-kebohongan-ini-faktanya.

Barclay, D. A. (2018). Fake News, Propaganda, and Plain Old Lies: How to Find Trustworthy Information in the Digital Age. London: Rowman \& Littlefield.

BBC. (2020, 05 27). Retrieved 01 01, 2021, from https://www.bbc.com/news/technology-52815552

Bergmann, E. (2020). Populism and the Politics of Misinformation. The Journal Of South African And American Studies, 21(3), 251-265.

Buccoliero, L., Bellio, E., Crestini, G., \& and Arkoudas, A. (2018). Twitter and 
Politics: Evidence From the US Presidential Elections 2016. Journal of Marketing Communications, 26(1), 88-114.

Carr, N. (2018, 01 26). Retrieved 01 07, 2021, from https:/www.politico.com/magazine/story/2018/01/26/donald-trumptwitter-addiction-216530/

Clayton, J. (2021, 05 05). Retrieved 05 20, 2021, from https://www.bbc.com/news/technology-56989500

Coll, S. (2017, 12 03). Retrieved 01 04, 2021, from https://www.newyorker.com/magazine/2017/12/11/donald-trumpsfake-news-tactics

Crawford, K. (2017, 01 18). Retrieved 02 09, 2021, from https://news.stanford.edu/2017/01/18/stanford-study-examines-fakenews-2016-presidential-election/

Denchak, M. (2021, 02 19). Retrieved 03 01, 2021, from https://www.nrdc.org/stories/paris-climate-agreement-everything-youneed-know

Dinçer, S. (2018). Content Analysis in for Educational Science Research: MetaAnalysis, Meta-Synthesis, and Descriptive Content Analysis. Bartin University Journal of Faculty of Education, 7(1), 176-190.

Duffy, Andrew,. Tandoc, Edson., Ling, Rich. (2019). Too Good to be True, Too Good Not to Share: The Social Utility of Fake News. Information, Communication \& Society, 23(13), 1965-1979.

Ecker, U., Jetter, M., \& Lewandowsky, S. (2020, 11 12). Retrieved 02 14, 2021, from https://theconversation.com/how-trump-uses-twitter-to-distract-themedia-new-research-149847

Figueira, A., \& Oliveira, L. (2017). The current state of fake news: challenges and opportunities. CENTERIS - International Conference on ENTERprise Information Systems. Barcelona.

Gallup. (2017, 01 19). Retrieved 02 04, 2021, from https://news.gallup.com/poll/116479/barack-obama-presidential-jobapproval.aspx.

Gallup. (2021， 01 15). Retrieved 03 04, 2021, from https://news.gallup.com/poll/203198/presidential-approval-ratingsdonald-trump.aspx 
Gore, D. (2018, 05 22). Retrieved 05 01，2021，from https://www.khou.com/article/news/nation-now/fact-check-trumpwrongly-blames-democrats-for-his-border-policy-of-separatingfamilies/465-1d87a155-eb69-457a-985a-30c83d26745b

Hendricks, J., \& Schill, D. (2017). "The Social Media Election of 2016," in The 2016 US Presidential Campaign. London: Palgrave McMillan.

Humphrey, M. (2021, 02 08). Retrieved 03 05, 2021, from https://theconversation.com/i-analyzed-all-of-trumps-tweets-to-findout-what-he-was-really-saying-154532

Jacobson, L. (2019, 05 07). Retrieved 02 09, 2021, from https:/www.politifact.com/factchecks/2019/may/07/viral-image/factchecking-joe-biden-hunter-biden-and-ukraine/

Jamieson, A. (2017, 01 11). Retrieved 12 12, 2020, from https://www.theguardian.com/us-news/2017/jan/11/trump-attacks-cnnbuzzfeed-at-press-conference

Keith, T. (2019, 01 11). Retrieved 02 10, 2021, from https://www.npr.org/2019/01/11/683920624/once-a-fence-later-slatsalmost-always-a-wall-trumps-border-wall-contradictions

Kellner, D. (2018). Donald Trump and the Politics of Lying. In Post-Truth, Fake News (pp. 89-100). Singapore: Springer.

Kleinheksel, A., Rockich-Winston, N., Tawfik, H., \& Wyatt, T. R. (2020). Qualitative Research in Pharmacy Education: Demystifying Content Analysis. American Journal of Pharmaceutical Education, 84(1), 127-137.

Knight Foundation. (2018). Americans' Views of Misinformation in the News and How to Counteract it. Florida: Knight Foundation.

Lemire, J., Miller, Z., \& and Weissert, W. (2020, 11 08). Retrieved 01 15, 2021, from https://apnews.com/article/joe-biden-wins-white-house-apfd58df73aa677acb74fce2a69adb71f9

Levitz, E. (2017, 06 09). Retrieved 04 01， 2021, from https://nymag.com/intelligencer/2017/06/every-terrifying-thing-thatdonald-trump-has-done.html

Lewandowsky, S., Jetter, M., \& and Ecker, U. K. (2020). Using the President's Tweets to Understand Political Diversion In the Age of Social Media. Nature Communications, 11, 1-12. 
Lippert, T. (2016). NATO, Climate Change, and International Security. RAND Corporation.

Maldonado, M. (2019). Understanding Fake News: Technology, Affects, and the Politics of the Untruth. Historia comunicación social, 24(2), 533-546.

McCarthy, N. (2021, 01 12). Retrieved 03 04, 2021, from https://thewire.in/world/donald-trump-twitter-chart

Mitchell, A., \& Gottfried, J. G. (2019, 06 15). Retrieved 02 14, 2021, from https://www.journalism.org/2019/06/05/many-americans-say-made-upnews-is-a-critical-problem-that-needs-to-be-fixed/

Morris, J. (2020). Simulacra in the Age of Social Media: Baudrillard as the Prophet of Fake News. Journal of Communication Inquiry.

Muqsith, M., Muzykant, V., Pratomo, R., \& Setiawan, R. (2020). Media Discourse of Roots Causes and Security Perspectives on Climate Change. International Journal of Progressive Sciences and Technologies, 23(1), 300-310.

Muqsith, M., Pratomo, R. R., Kuswanti, A., \& Muzykant, V. (2021). Social solidarity movement to prevent the spread of COVID-19 pandemic in Indonesia. Journal Masyarakat, Kebudayaan dan Politik, 34(2), 147-158.

Nusselder, A. (2013). Twitter and the Personalization of Politics. Psychoanalysis, Culture \& Society, 18, 91-100.

Pain, P., \& CHen, G. (2019). The President Is in: Public Opinion and the Presidential Use of Twitter. Social Media + Society, 5(2), 1-12.

Pew Research Center. (2021, 01 20). Retrieved 04 05, 2021, from https://www.pewresearch.org/2021/01/29/how-america-changedduring-donald-trumps-presidency/

Pew Research Center Logo. (2020, 02 21). Retrieved 01 05, 2021, from https://www.pewresearch.org/internet/2020/02/21/concerns-aboutdemocracy-in-the-digital-age/

Quandt, T., Frischlich, L., Boberg, S., \& \& Schatto-Eckrodt, T. (2019). "Fake News," in The International Encyclopedia of Journalism Studies. New Jersey,: John Wiley \& Sons, Inc.

Robertson, A. (2019, 12 03). Retrieved 01 02, 2021, from https://www.theverge.com/21276897/fake-news-facebook-twittermisinformation-lies-fact-check-how-to-internet-guide

Roca-Cuberes, C., \& Young, A. (2020). Vox Populi? Trump's Twitter Page as 
Public Forum. MDPI Social Sciences, 9, 226.

Rosenberg, B., Williams, T. R., \& and nimashaun, C. A. (2020, 11 09). Retrieved 02 03, 2021, from https://www.vox.com/2020/11/8/21550345/50-millionconfirmed-cases-covid-19-worldwide

Sacchetti, M. (2021, 04 11). Retrieved 05 01, 2021, from https://www.washingtonpost.com/immigration/congress-citizenshiplegislation/2021/04/09/e0f32e4c-8dbd-11eb-942304079921c915_story.html

Salkowitz, R. (2017, 01 17). Retrieved 12 12, 2020, from https:/www.forbes.com/sites/robsalkowitz/2017/01/17/trumps-20million-twitter-followers-get-smaller-under-themicroscope/?sh=7f3d8d954407

Schroeder, R. (2019). Digital Media and the Entrenchment of Right-Wing Populist Agendas. Social Media + Society.

Snith, T. (2020, 11 11). Retrieved 05 21, 2021, from https://abcnews.go.com/Politics/trump-longstanding-history-callingelections-rigged-doesnt-results/story?id=74126926

Somu, S. (2020, 07 17). Retrieved 05 21, 2021, from https:/jakartaglobe.id/opinion/wrong-to-use-china-as-scapegoat-forcovid19

Tandoc, E. J. (2018). Defining 'Fake. Digital Journalism, 6(2), 137-153.

Tsfati, Y., Boomgaarden, H., Strömbäck, J., Vliegenthart, R., Damstra, A., \& and Lindgren, E. (2020). Causes and Consequences of Mainstream Media Dissemination of Fake News: Literature Review and Synthesis. Annals of the International Communication Association.

van der Linden, S. P. (2020). You are fake news: political bias in perceptions of fake news. Media, Culture \& Society, 42(3), 460-470.

Wakefield, J. (2021, 03 25). Retrieved 04 02, 2021, from https://www.bbc.com/news/technology-56523378

Walsh, T. (2017, 01 06). Retrieved 12 15, 2020, from https://www.usnews.com/news/ken-walshs-washington/articles/201701-06/trump-uses-twitter-as-strategic-weapon

Wang, M., Rao, M., \& and Sun, Z. (2020). Typology, Etiology, and Fact-Checking: A Pathological Study of Top Fake News in China. Journalism Practice, 1- 
20.

Wardle, C., \& Derakhshan, D. H. (2017). INFORMATION DISORDER: Toward an interdisciplinary framework for research and policy making. Strasbourg Cedex: the Council of Europe.

Whitling, A., \& Williams, D. (2013). Why people use social media: a uses and gratifications approach. Qualitative Market Research: An International Journal, 16(4), 362-369.

Wilson, V. (2016). Research Methods: Content Analysis. Evidence Based Library and Information Practice, 11(1), 177-179.

Woodward, A. (2020, 10 02). Retrieved 03 04, 2021, from https://www.independent.co.uk/news/world/americas/uselection/trump-fake-news-counter-history-b732873.html

WORLAND, J. (2016, 10 04). Retrieved 02 01, 2021, from https://time.com/4517326/climate-change-public-opinion/

Zúñiga, H. G. (2020). Populism in the era of Twitter: How social media contextualized new insights into an old phenomenon. New Media $\mathcal{E}$ Society, 22(4), 585-594. 